\title{
Application of tissue engineering in stem cell therapy
}

\author{
Jong Kyu Hong ${ }^{1}$, Sang Mo Kwon ${ }^{1,2}$ \\ ${ }^{1}$ Laboratory for Vascular Medicine and Stem Cell Biology, Convergence Stem Cell Research Center, Medical Research Institute, \\ Pusan National University School of Medicine, Yangsan, Republic of Korea \\ ${ }^{2}$ Immunoregulatory Therapeutics Group in Brain Busan 21 Project, Busan, Republic of Korea \\ Email:smkwon323@hotmail.com
}

Received 17 October 2013; revised 25 November 2013; accepted 7 December 2013

Copyright (C 2014 Jong Kyu Hong, Sang Mo Kwon. This is an open access article distributed under the Creative Commons Attribution License, which permits unrestricted use, distribution, and reproduction in any medium, provided the original work is properly cited. In accordance of the Creative Commons Attribution License all Copyrights (C 2014 are reserved for SCIRP and the owner of the intellectual property Jong Kyu Hong, Sang Mo Kwon. All Copyright (C 2014 are guarded by law and by SCIRP as a guardian.

\section{ABSTRACT}

Tissue engineering based on stem cells has gained interest recently as attempts are made to engineer scaffold environments mimicking the stem cell niche, which contains a reservoir of multipotent stem cells that can maintain normal tissue or restore unhealthy cell populations in response to mechanisms of quiescence, self-renewal, and differentiation of the stem cells. These cell behaviors are governed by soluble signals that are systemic or presented by local niche cells. In this review, current and emergent approaches based on stem cells in the field of tissue engineering are presented for specific applications of human tissues and organs. The combination of stem cells and tissue engineering opens new perspectives in tissue regeneration for stem cell therapy because of the potential to control stem cell behavior with the physical and chemical characteristics of the engineered scaffold environment.

\section{KEYWORDS}

Stem Cell; Cell Behavior; Scaffold; Tissue Engineering; Tissue Regeneration

\section{INTRODUCTION}

\subsection{Tissue Engineering}

Chronic limitations of traditional transplantation surgeries still exist due to the lack of appropriate donor tissues, risk of disease transmission, and potential for immune rejection. Tissue engineering, the multidisciplinary application of biology, chemistry, physics, engineering, and medical science, offers an alternative method to overcome these issues [1,2]. For therapeutic application of tissue engineering, engineered tissue is grown either within a patient or outside the patient and subsequently transplanted into the patient. Figure 1 provides a schematic representation of the process of tissue regeneration in tissue engineering. Human cells are harvested from a patient and after in vitro cell culture, cells are seeded onto scaffolds with medium containing chemical stimuli, such as growth factors and differentiation-inducing factors. Scaffolds are three-dimensional (3D) matrices that support cellular growth processes, such as cell adhesion, migration, proliferation, and differentiation, by which cells are colonized onto the scaffold. The cell-colonized scaffold is then implanted into the patient, to regenerate biocompatible, immunocompatible, and biofunctional tissues or organs inside the patient body. Cells and scaffolds are essential to regenerate new tissues with tissue engineering. Cells become the primary component of the engineered tissue and the scaffold provides cells with an appropriate physical and chemical environment where they

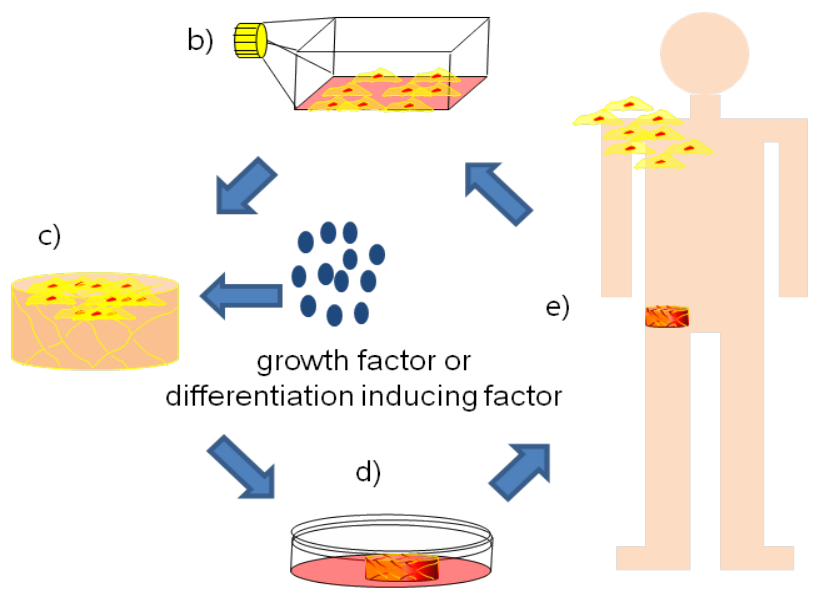

Figure 1. a) Tissue harvested from a patient's body to obtain cells b) in vitro cell culture c) a scaffold seeded with cells d) in vitro cell culture for cell colonization of the scaffold e) implantation of cell-colonized scaffold within the patient. 
can attach to the surface of the scaffold, migrate through the scaffolds' pores, and then proliferate. In some instances, such as stem cell therapy, collaboration of cells and scaffolds with differentiation-inducing factors is essential for stem cells to differentiate into engineered cell lineages and to develop new tissues.

\subsection{Stem Cells}

Although it is difficult to grow some cell types such as cardiomyoctes (CMs) and hepatocytes in large quantities, stem cells are undifferentiated biological cells that can produce more stem cells (self-renewal) and can differentiate into specialized cells (cell potency). Two broad types of stem cells exist: embryonic stem cells (ESCs) isolated from the inner cell mass of blastocysts, and adult stem cells found in various tissues, including the dermis [3], bone marrow [4], blood [5], muscle [6], adipose tissue [7], etc. Use of ESCs has been limited for tissue engineering because of the legal and ethical concerns regarding use of human ESCs [8]. These issues are less prevalent for adult stem cells, and as a result, adult stem cells, such as skeletal stem cells [9], neuronal stem cells [10] and mesenchymal stem cells (MSCs) [11] from human or non-human sources in tissue engineering have been widely investigated. For example, MSCs are used in tissue engineering because of their availability in various sources (bone marrow [12], muscle [6], trabecular bone [13], dermis [3], adipose tissue [7], periosteum [14], blood [5], and synovial membrane [15]); and their ability to differentiate to multiple connective tissue cell types (osteocytes [16], chondrocytes [17], adipocytes [18], and myocytes [19]) and other cell types (hepatocytes [20] and neuron [21]) in response to extracellular stimuli, including differentiation-inducing factors from protein and chemical origins. Biological growth factors from protein sources can induce differentiation of stem cells; chemical agents are also used for the specific differentiation of stem cells in vitro. Transforming growth factors beta 1 and 3 (TGF- $\beta 1$ and TGF- $\beta 3$ ), for example, have been reported to enhance the differentiation of MSCs to chondrocytes [22] and the chemical agent $\beta$-mercaptoethanol (BME) has been used for neural transdifferentiation of MSCs [23].

\subsection{Scaffolds}

A scaffold is a 3D matrix that provides the framework and initial structural support for cells to attach, proliferate, and differentiate, facilitating the formation of an extracellular matrix (ECM) [24]. Characteristics of an ideal scaffold include: 1) contains a network of interconnecting pores so that cells can attach, proliferate, and migrate throughout the entire scaffold; 2) has channels through which oxygen and nutrients are provided to cells and waste products are carried out; 3 ) is biocompatible with a high affinity for cells to attach and proliferate; and 4) has appropriate mechanical properties [25]. Various processing techniques have been used for fabricating scaffolds which have biocompatibility and appropriate surface properties to support cellular attachment, proliferation and differentiation [25]. Examples of scaffold fabrication methods include emulsion/freeze-drying [26], solvent casting/particular leaching [27], computer-aided design/computer-aided manufacturing [28], electrospinning [28], nanofiber self-assembly [29], and photolithography [30].

For cell based tissue engineering, cells are usually seeded onto scaffolds which are made of materials such as acellular tissue matrices, naturally derived materials (natural biomaterials), and synthetic polymers (synthetic biomaterials). Acellular tissue matrices may be animal or human-derived with all cells removed during manufacture [31-33] and natural biomaterials extracted from animal sources, such as fibrin [34], collagen [35], gelatin [36], chitosan [37], alginate [38], hyaluronic acid [39], etc. Synthetic biomaterials fabricated from laboratories or factories, such as polycaprolactone (PCL) [40], polylactic acid (PLA) [41], poly(glycolic acid) (PGA) [42], poly(d,l-lactic-co-glycolic acid) (PLGA) [43], polyvinyl alcohol (PVA) [44], polyethyleneglycol (PEG) [45], polyurethanes, carbon nanotubes (CNT) [46], $\mathrm{TiO}_{2}$ nanotubes [47], etc. are also widely used. Synthetic biomaterials have tunable mechanical properties, however, the biocompatibility of natural biomaterials is better than synthetic materials, thus, hybrids of natural and synthetic materials are also used for scaffold fabrication. To support tissue regeneration for in vitro stem cell study, differentiation-inducing factors can be loaded into scaffolds to promote and to induce differentiation of stem cells, but these factors under specific circumstances remain indispensable. Achieving success in tissue engineering is attributed only to stem cells and scaffolds, suggesting that the effects of differentiation factors may be substituted with suitable scaffold structures [1].

\section{STEM CELLS IN TISSUE ENGINEERING}

Tissue engineering may be used for tissue regeneration such as bone, cartilage and neural tissues using degradable biomaterial scaffolds. For example, tubular collagen nerve guides (Neuragen from Integra Life Sciences) were used clinically to treat peripheral nerve injuries and the critical gap length treated by nerve guides was longer than $10 \mathrm{~mm}$ in primates and could be further increased by adding fibers or hydrogel with cells [48]. In addition, tissue-engineered constructs for bone was osteoconductive to enhance bone cells to adhere, proliferate and migrate. For instance, PCL based scaffolds using fused deposition modeling was developed, approved by the 
FDA and used clinically as burr plugs and sheets for orbital floor reconstruction in more than 200 patients [49]. In addition, tissue engineering treatments for cartilage repair have been established clinically but are not widespread because of limitations in efficiency, consistency and applicability [50]. Furthermore, stem cells are used in in the field of various tissue engineering such as cardiac, neural, bone, liver tissue engineering, etc. and some examples of the use of scaffolds, biomaterials, and stem cells in tissue engineering were summarized in Table 1.

\subsection{Cardiac Tissue Engineering}

Congestive heart failure, resulting from myocardial infarction (MI) and ischemic loss of functional CMs, remains the leading cause of death in the United States [51]. The complex events involved in ischemic myocardial cell loss, and the subsequent post-MI remodeling leading to heart failure are not efficiently addressed by existing therapies [52]. Tissue engineering and stem cell therapy could be a promising approach for cardiac repair. Natural acellular scaffolds made of hydrogels have the mechanical structure to support the infarcted heart, reducing wall stress, compensating for contraction function, and inhibiting ventricle remodeling. In vivo study has shown that hydrogels alone can provide mechanical support to the infarcted heart by attenuating wall stress, compensating for contraction function and preventing ventricle remodeling [45]. Basic fibroblast growth factor (bFGF) plays an important role in angiogenesis and bFGF encapsulated in heparin-alginate microspheres, within a pig model of chronic MI, demonstrated significant enhancement in myocardial function in vivo [53]. Hydrogel scaffolds have also been used in vitro for cell expansion and the induction of cardiogenic differentiation. For example, cell-cell interactions of aggregates of CMs, derived from skeletal muscle-derived stem cells (MDSCs), were enhanced in collagen scaffolds. The expression of cardiac genes, including connexin 43 and cardiac troponin-T were also enhanced, suggesting that MDSCs within collagen scaffolds is a useful 3D culture system to directly assess the contractile properties of differentiated CMs in vitro [54]. In addition, evaluation of a composite scaffold made of the natural and synthetic biomaterials, collagen and PGA, in a perfusion bioreactor demonstrated enhanced attachment of cardiac stem cells (CSCs) [55]. Moreover, physical stimuli such as mechanical stress promoted 2-fold increases in CMs, in addition to matrix fiber alignment, myofibrillogenesis and sarcomeric banding, while cyclic mechanical stress increased CM hypertrophy (2.2-fold) and proliferation rates (21\%) when compared to controls with no mechanical stress [56].

\subsection{Neural Tissue Engineering}

The central nervous system (CNS), consisting of the spinal cord and the brain, is a very unique tissue network with an unusual ECM structure and characteristic soft physical properties (elastic modulus of natural brain tissue is around $500 \mathrm{~Pa})$ when compared to muscle $\left(10^{4} \mathrm{~Pa}\right)$ and bone $\left(10^{9}-10^{10} \mathrm{~Pa}\right)$, which is susceptible to damage, illnesses, and injuries, including traumatic brain injury, spinal cord injury, stroke, Parkinson's disease, and multiple sclerosis $[57,58]$. The mechanical properties, structure, and composition of the ECM are effectors of cell function, thus, soft hydrogel scaffolds are utilized for

Table 1. Scaffold biomaterials and stem cells used in tissue engineering.

\begin{tabular}{|c|c|c|c|}
\hline Applications & Scaffold & Components & Stem cells \\
\hline Cardiac tissue engineering & Injectable hydrogel [45] & alpha-CD/PEG-PCL-PEG & $\mathrm{N} / \mathrm{A}$ \\
\hline Cardiac tissue engineering & Injectable microsphere [53] & bFGF/heparin-alginate & N/A \\
\hline Cardiac tissue engineering & Hydrogel [54] & collagen & CMs derived from skeletal MDSCs \\
\hline Cardiac tissue engineering & Sponge/nanofiber [55] & PGA/collagen & CSCs \\
\hline Cardiac tissue engineering & Hydrogel [56] & Collagen & hiPSCs \\
\hline Neural tissue engineering & Hydrogel [60] & PDGF-AA/agarose & NSCs/NPCs \\
\hline Neural tissue engineering & Hydrogel [61] & $\mathrm{RADA}_{16} / \mathrm{IKVAV}$ & NSCs \\
\hline Neural tissue engineering & Thin film [62] & Laminin/SWCNT & NSCs \\
\hline Neural tissue engineering & Fibrous mesh [63] & PLLA/PANi & NSCs \\
\hline Bone tissue engineering & Fibrous mesh [65] & PLGA/collagen/hydroxyapatite & hMSCs \\
\hline Bone tissue engineering & Hydrogel [67] & ACP/collagen & hMSCs \\
\hline Bone tissue engineering & Sponge [68] & cMWCMT/PLGA & rMSCs \\
\hline Bone tissue engineering & Spheroid [69] & N/A & bmMSC/HUVEC \\
\hline Liver tissue engineering & Fibrous mesh [71] & PLGA & mESC \\
\hline Liver tissue engineering & Fibrous mesh [72] & PCL/collagen/polyethersulfone & hMSC \\
\hline
\end{tabular}


CNS applications to mimic the biochemical and mechanical properties of the CNS [58]. For instance, hydrogel scaffolds made of acrylamide and PEG with arginineglycine-aspartic acid (RGD) can regulate cell behaviors, such as adhesion, cell renewal, and differentiation of neural stem cells (NSCs) [59]. Platelet-derived growth factor (PDGF)-AA immobilized agarose scaffolds have been reported to support differentiation of NSCs and neural progenitor cells (NPCs) to oligodendrocytes [60]. Hydrogel scaffolds made of AcN-RADARADARADARADAIKVAV-CONH ${ }_{2}\left(\mathrm{RADA}_{16}\right.$-IKVAV) have been shown to serve as a guiding cue to direct NSC adhesion and neural differentiation with in vitro and in vivo to direct stem cell differentiation toward neural lineages and to promote the signal transmission among neurons because of electrical conductivity. The hydrogel in a rat brain surgery model enhanced survival of NSCs, reduced the formation of glial astrocytes, and improved brain tissue regeneration after 6 weeks post-transplantation [61]. In addition, CNT is used. For example, electrical stimulation was shown to enhance the proliferation and differentiation of NSCs on thin film scaffolds made of laminin and single-wall carbon nanotubes (SWCNT) [62]. Bioelectricity also has been shown to affect intercellular signaling of the nervous system, as fibrous scaffolds made of poly-l-lactide/polyaniline (PLLA/PANi), applied with an electric field of $100 \mathrm{mV} / \mathrm{mm}$ for a period of $60 \mathrm{~min}-$ utes, showed extended neurite outgrowth compared to cells grown on non-stimulated scaffolds [63].

\subsection{Bone Tissue Engineering}

Bone is a connective tissue consisting of a collagenous ECM that is extensively mineralized with hydroxyapatite $\left(\mathrm{Ca}_{10}\left[\mathrm{PO}_{4}\right]_{6}[\mathrm{OH}]_{2}\right)$ and other ions that contribute to the high density and strength of bone, as well as its homeostatic regulation and metabolic function [64]. Collagen, however, has poor structural stability, thus, scaffolds made of hybrid materials, consisting of natural and synthetic components, are utilized in bone tissue engineering. For example, fibrous scaffolds made of PLGA/collagen/hydroxyapatite were shown to provide structural stability and mechanical integrity, as well as improve human MSC (hMSC) binding [65]. Inorganic materials such as calcium phosphate [66] or amorphous calcium phosphate (ACP) [67] may enhance the structural stability of collagen scaffolds. Scaffolds made of a composite of collagen and ACP, for example, have been shown to support the proliferation and osteogenic differentiation of MSCs [67], while rat MSCs (rMSCs) on carboxyl-functionalized MWCNT (cMWCNT)/PLGA composites showed enhanced levels of alkaline phosphatase produced by osteoblasts [68]. In addition, bone is a highly metabolic tissue requiring an abundant vascular supply throughout its structure for homeostasis, growth, and remodeling. As a result, 3D co-culture systems based on biomaterials have been studied for concurrent angiogenesis/vasculogenesis and osteogenesis. A spheroid co-culture system of bone marrow derived mesenchymal stromal cells (bmMSC) and human dermal microvascular endothelial cells (HUVECs) produced well-organized 3D vascular structures in vitro and resulted in increased alkaline phosphatase expression when compared to a control culture system of bmMSCs and fibroblasts [69].

\subsection{Liver Tissue Engineering}

The liver is the largest organ in the human body and has major roles in metabolism, detoxification, and protein synthesis. Hepatocytes, the major cell type in the liver, execute most of the metabolic, synthetic and storage functions of the liver. The interactions between hepatocytes and non-parenchymal cells also affect the function of the liver. Within in vitro culture environments, hepatocytes tend to lose their function, suggesting that stem cells could be an alternative cell source in combination with supplementary factors, such as differentiation-inducting factors, for liver tissue engineering [70]. Evaluation of rat ESCs (rESCs) cultured within a 3D culture system were shown to differentiate into hepatic-like cells with morphological characteristics of typical mature hepatocytes in the presence of supplementary factors, such as recombinant mouse hepatic growth factor, fibroblast growth factor, insulin, transferrin, selenium, oncostatin, and dexamethasone. Additionally, when these stem cellbearing scaffolds were transplanted into severe combined immunodeficient mice, the rESCs remained viable, undergoing further differentiation and maturation of hepatic-like cells in vivo [71]. Studies of PCL/collagen/polyethersulfone composite scaffolds showed that these scaffolds promoted hMSC differentiation to hepatocytelike cells and the expression of hepatocyte-specific markers, such as albumin, $\alpha$-fetoprotein, cytokeratin-18, cytokeratin-19, and cytochrome P450 3A4 at mRNA levels, where the number of albumin-positive cells cultured on the scaffold $(47 \% \pm 4 \%)$ was higher than that in the two-dimensional culture system $(28 \% \pm 6 \%)$ in vitro [72]. However, additional functional assessment of hepatocytelike cells was needed because of the uncertainty of their functionality when compared to adult hepatocytes.

\subsection{Other Applications}

In addition to cardiac muscle, nerve, bone, and liver applications as described above, the combination of stem cells and tissue engineering could apply to regenerate other tissue types, such as the eyes [73], cartilage [74], skin [75], bladder [75], and tendon [76]. Clinical trials of strategies using a combination of tissue engineering and 
stem cells to regenerate bladder, kidney, and urethra tissue are already underway [77].

\section{CONCLUSIONS AND FUTURE PERSPECTIVES}

Advancements in the fields of stem cell biology and biomaterials science and engineering have been combined to produce strategies by which stem cell attachment, proliferation and differentiation in vitro are supported and enhanced. Although the combination of stem cells and tissue engineering is currently in the research phase and still far from clinical application, the combination of tissue engineering and stem cell biology has greatly enhanced the possibility of tissue regeneration. However, many different biomaterials such as nanobiomaterials that have not adapted for use with stem cell culture could be studied in near future. Meanwhile, the application of tissue engineering to stem cell therapy in vivo is highly expected to progress in the near future. Other future consideration for tissue engineering based on stem cell therapy is how to develop many methods of incorporating and producing a vascular network in a scaffold, allowing it to integrate with actual tissue or organs and restore function lost after injury. It could be achieved by co-culturing with endothelial cells or by embedding angiogenic factors such as vascular endothelial growth factors to promote angiogenesis into scaffolds. Overall, this review paper has provided a good starting point for future development of tissue engineering combined with biomaterial scaffolds for stem cell therapy.

\section{ACKNOWLEDGEMENTS}

This work was supported by grants from the National Research Foundation funded by the Korean government (MEST; 2010-0020260, NRF-2012R1A2A2A01045085, 2012M3A9C6049720).

\section{REFERENCES}

[1] Zhao, C., Tan, A., Pastorin, G. and Ho, H.K. (2013) Nanomaterial scaffolds for stem cell proliferation and differentiation in tissue engineering. Biotechnology Advances, 31, 654-668.

http://dx.doi.org/10.1016/j.biotechadv.2012.08.001

[2] Langer, R. and Vacanti J. (1993) Tissue engineering. Science, 260, 920-926. http://dx.doi.org/10.1126/science.8493529

[3] Young, H.E., Steele, T.A., Bray, R.A., Hudson, J., Floyd, J.A., Hawkins, K., Thomas, K., Austin, T., Edwards, C., Cuzzourt, J., Duenzl, M., Lucas, P.A. and Black Jr., A.C. (2001) Human reserve pluripotent mesenchymal stem cells are present in the connective tissues of skeletal muscle and dermis derived from fetal, adult, and geriatric donors. The Anatomical Record, 264, 51-62. http://dx.doi.org/10.1002/ar.1128

[4] Pittenger, M.F., Mackay, A.M., Beck, S.C., Jaiswal, R.K.,
Douglas, R., Mosca, J.D., Moorman, M.A., Simonetti, D.W., Craig, S. and Marshak, D.R. (1999) Multilineage potential of adult human mesenchymal stem cells. Science, 284, 143-147.

http://dx.doi.org/10.1126/science.284.5411.143

[5] Zvaifler, N.J., Marinova-Mutafchieva, L., Adams, G., Edwards, C.J., Moss, J., Burger, J.A. and Maini, R.N. (2000) Mesenchymal precursor cells in the blood of normal individuals. Arthritis Research, 2, 477-488.

http://dx.doi.org/10.1186/ar130

[6] Wada, M.R., et al. (2002) Generation of different fates from multipotent muscle stem cells. Development, 129, 2987-2995.

[7] Gronthos, S., Franklin, D.M., Leddy, H.A., Robey, P.G., Storms, R.W. and Gimble, J.M. (2001) Surface protein characterization of human adipose tissue-derived stromal cells. Journal of Cellular Physiology, 189, 54-63. http://dx.doi.org/10.1002/jcp.1138

[8] Green, R.M. (2007) Can we develop ethically universal embryonic stem-cell lines? Nature Reviews Genetics, 8, 480-485. http://dx.doi.org/10.1038/nrg2066

[9] Biggs, M.J.P., Richards, R.G., Gadegaard, N., Wilkinson, C.D.W., Oreffo, R.O.C. and Dalby, M.J. (2009) The use of nanoscale topography to modulate the dynamics of adhesion formation in primary osteoblasts and ERK/ MAPK signalling in STRO-1+ enriched skeletal stem cells. Biomaterials, 30, 5094-5103.

http://dx.doi.org/10.1016/j.biomaterials.2009.05.049

[10] Low, W.C., Rujitanaroj, P.-O., Lee, D.-K., Messersmith, P.B., Stanton, L.W., Goh, E. and Chew, S.Y. (2013) Nanofibrous scaffold-mediated REST knockdown to enhance neuronal differentiation of stem cells. Biomaterials, 34, 3581-3590.

http://dx.doi.org/10.1016/j.biomaterials.2013.01.093

[11] Shih, D.T.-B., Lee, D.-C., Chen, S.-C., Tsai, R.-Y., Huang, C.-T., Tsai, C.-C., Shen, E.-Y. and Chiu, W.-T. (2005) Isolation and characterization of neurogenic mesenchymal stem cells in human scalp tissue. STEM CELLS, 23, 1012-1020. http://dx.doi.org/10.1634/stemcells.2004-0125

[12] Ferrari, G., Cusella, G., Angelis, D., Coletta, M., Paolucci, E., Stornaiuolo, A., Cossu, G. and Mavilio, F. (1998) Muscle regeneration by bone marrow-derived myogenic progenitors. Science, 279, 1528-1530. http://dx.doi.org/10.1126/science.279.5356.1528

[13] Nöth, U., Osyczka, A.M., Tuli, R., Hickok, N.J., Danielson, K.G. and Tuan, R.S. (2002) Multilineage mesenchymal differentiation potential of human trabecular bonederived cells. Journal of Orthopaedic Research, 20, 1060-1069. http://dx.doi.org/10.1016/S0736-0266(02)00018-9

[14] Nakahara, H., Goldberg, V.M. and Caplan, A.I. (1991) Culture-expanded human periosteal-derived cells exhibit osteochondral potential in vivo. Journal of Orthopaedic Research, 9, 465-476. http://dx.doi.org/10.1002/jor.1100090402

[15] De Bari, C., Dell’Accio, F. and Luyten, F.P. (2001) Human periosteum-derived cells maintain phenotypic stability and chondrogenic potential throughout expansion re- 
gardless of donor age. Arthritis \& Rheumatism, 44, 85-95. http://dx.doi.org/10.1002/1529-0131(200101)44:1<85::AI D-ANR12>3.0.CO;2-6

[16] Bosch, P., Musgrave, D.S., Lee, J.Y., Cummins, J., Shuler, F., Ghivizzani, S.C., Evans, C., Robbins, P.D. and Huard, J. (2000) Osteoprogenitor cells within skeletal muscle. Journal of Orthopaedic Research, 18, 933-944. http://dx.doi.org/10.1002/jor.1100180613

[17] Nobuo, A., et al. (2002) Muscle derived, cell based ex vivo gene therapy for treatment of full thickness articular cartilage defects. Journal of Rheumatology, 29, 19201930.

[18] Bianco, P., Costantini, M., Dearden, L.C. and Bonucci, E. (1988) Alkaline phosphatase positive precursors of adipocytes in the human bone marrow. British Journal of Haematology, 68, 401-403. http://dx.doi.org/10.1111/j.1365-2141.1988.tb04225.x

[19] Martins, A., Alves da Silva, M.L., Faria, S., Marques, A.P., Reis, R.L. and Neves, N.M. (2011) The influence of patterned nanofiber meshes on human mesenchymal stem cell osteogenesis. Macromolecular Bioscience, 11, 978987. http://dx.doi.org/10.1002/mabi.201100012

[20] Petersen, B.E., Bowen, W.C., Patrene, K.D., Mars, W.M., Sullivan, A.K., Murase, N., Boggs, S.S., Greenberger, J.S. and Goff, J.P. (1999) Bone marrow as a potential source of hepatic oval cells. Science, 284, 1168-1170. http://dx.doi.org/10.1126/science.284.5417.1168

[21] Dan, Y.Y. (2009) Bioengineering the artificial liver with non-hepatic cells: Where are we headed? Journal of Gastroenterology and Hepatology, 24, 171-173. http://dx.doi.org/10.1111/j.1440-1746.2008.05711.x

[22] Park, J.S., Yang, H.N., Woo, D.G., Jeon, S.Y. and Park, K.-H. (2011) Chondrogenesis of human mesenchymal stem cells in fibrin constructs evaluated in vitro and in nude mouse and rabbit defects models. Biomaterials, 32, 1495-1507. http://dx.doi.org/10.1016/j.biomaterials.2010.11.003

[23] Prabhakaran, M.P., Venugopal, J.R. and Ramakrishna, S. (2009) Mesenchymal stem cell differentiation to neuronal cells on electrospun nanofibrous substrates for nerve tissue engineering. Biomaterials, 30, 4996-5003. http://dx.doi.org/10.1016/j.biomaterials.2009.05.057

[24] Agrawal, C.M. and Ray, R.B. (2001) Biodegradable polymeric scaffolds for musculoskeletal tissue engineering. Journal of Biomedical Materials Research, 55, 141-150. http://dx.doi.org/10.1002/1097-4636(200105)55:2<141:: AID-JBM1000>3.0.CO;2-J

[25] Liu, C., Xia, Z. and Czernuszka, J.T. (2007) Design and development of three-dimensional scaffolds for tissue engineering. Chemical Engineering Research and Design, 85, 1051-1064. http://dx.doi.org/10.1205/cherd06196

[26] Whang, K., Thomasa, C.H. and Healy, K.E. (1995) A novel method to fabricate bioabsorbable scaffolds. Polymer, 36, 837-842.

http://dx.doi.org/10.1016/0032-3861(95)93115-3

[27] Mikos, A.G., Thorsen, A.J., Czerwonka, L.A., Bao, Y., Langer, R., Winslow, D.N. and Vacanti, J.P. (1994) Preparation and characterization of poly(l-lactic acid) foams. Polymer, 35, 1068-1077. http://dx.doi.org/10.1016/0032-3861(94)90953-9

[28] Silva, N.R.F.A., Witek, L., Coelho, P.G., Thompson, V.P., Rekow, E.D. and Smay, J. (2011) Additive CAD/CAM Process for Dental Prostheses. Journal of Prosthodontics, 20, 93-96. http://dx.doi.org/10.1111/j.1532-849X.2010.00623.x

[29] Luo, Z., Wang, S. and Zhang, S. (2011) Fabrication of self-assembling d-form peptide nanofiber scaffold dEAK16 for rapid hemostasis. Biomaterials, 32, 20132020.

http://dx.doi.org/10.1016/j.biomaterials.2010.11.049

[30] Liu, B., Liu, Y., Lewis, A.K. and Shen, W. (2010) Modularly assembled porous cell-laden hydrogels. Biomaterials, 31, 4918-4925.

http://dx.doi.org/10.1016/j.biomaterials.2010.02.069

[31] Sano, H., Orbay, H., Terashi, H., Hyakusoku, H. and Ogawa, R. (2014) Acellular adipose matrix as a natural scaffold for tissue engineering. Journal of Plastic, Reconstructive \& Aesthetic Surgery, 67, 99-106. http://dx.doi.org/10.1016/j.bjps.2013.08.006

[32] Ohkuma, R., et al., (2013) Initial experience with the use of foetal/neonatal bovine acellular dermal collagen matrix (SurgiMend $^{\mathrm{TM}}$ ) for tissue-expander breast reconstruction. Journal of Plastic, Reconstructive \& Aesthetic Surgery, 66, 1195-1201. http://dx.doi.org/10.1016/j.bjps.2013.05.004

[33] Wu, C., Cipriano, J., Osgood, Jr., G., Tepper, D. and Siddiqui, A. (2013) Human acellular dermal matrix (AlloDerm $\left.{ }^{\circledR}\right)$ dimensional changes and stretching in tissue expander/implant breast reconstruction. Journal of Plastic, Reconstructive \& Aesthetic Surgery, 66, 1376-1381. http://dx.doi.org/10.1016/j.bjps.2013.05.018

[34] Hokugo, A., Takamoto, T. and Tabata, Y. (2006) Preparation of hybrid scaffold from fibrin and biodegradable polymer fiber. Biomaterials, 27, 61-67. http://dx.doi.org/10.1016/j.biomaterials.2005.05.030

[35] Engelhardt, E.-M., Micol, L.A., Houis, S., Wurm, F.M., Hilborn, J., Hubbell, J.A. and Frey, P. (2011) A collagen-poly(lactic acid-co- $\varepsilon$-caprolactone) hybrid scaffold for bladder tissue regeneration. Biomaterials, 32, 39693976. http://dx.doi.org/10.1016/j.biomaterials.2011.02.012

[36] Mao, J.S., Zhao, L.G., Yin, Y.J. and Yao, K.D. (2003) Structure and properties of bilayer chitosan-gelatin scaffolds. Biomaterials, 24, 1067-1074. http://dx.doi.org/10.1016/S0142-9612(02)00442-8

[37] Duarte, A.R.C., Mano, J.F. and Reis, R.L. (2009) Preparation of chitosan scaffolds loaded with dexamethasone for tissue engineering applications using supercritical fluid technology. European Polymer Journal, 45, 141-148. http://dx.doi.org/10.1016/j.eurpolymj.2008.10.004

[38] Wang, C.C., Yang, K.C., Lin, K.H., Liu, H.C. and Lin, F.H. (2011) A highly organized three-dimensional alginate scaffold for cartilage tissue engineering prepared by microfluidic technology. Biomaterials, 32, 7118-7126. http://dx.doi.org/10.1016/j.biomaterials.2011.06.018

[39] Pieper, J.S., Hafmans, T., van Wachem, P.B., van Luyn, M.J.A., Brouwer, L.A., Veerkamp, J.H. and van Kuppe- 
velt, T.H. (2002) Loading of collagen-heparan sulfate matrices with bFGF promotes angiogenesis and tissue generation in rats. Journal of Biomedical Materials Research, 62, 185-194. http://dx.doi.org/10.1002/jbm.10267

[40] Hong, J.K. and Madihally, S.V. (2010) Three-dimensional scaffold of electrosprayed fibers with large pore size for tissue regeneration. Acta Biomaterialia, 6, 4734-4742. http://dx.doi.org/10.1016/j.actbio.2010.07.003

[41] Montjovent, M.O., Mark, S., Mathieu, L., Scaletta, C., Scherberich, A., Delabarde, C., Zambelli, P.Y., Bourban, P.E., Ann Applegate, L. and Pioletti, D.P. (2008) Human fetal bone cells associated with ceramic reinforced PLA scaffolds for tissue engineering. Bone, 42, 554-564. http://dx.doi.org/10.1016/j.bone.2007.10.018

[42] Lohmann, C.H., Schwartz, Z., Niederauer, G.G., Carnes, D.L., Dean, D.D. and Boyan, B.D. (2000) Pretreatment with platelet derived growth factor-BB modulates the ability of costochondral resting zone chondrocytes incorporated into PLA/PGA scaffolds to form new cartilage in vivo. Biomaterials, 21, 49-61. http://dx.doi.org/10.1016/S0142-9612(99)00132-5

[43] Yang, Y.Y., Zhao, Y.H., Tang, G.W., Li, H., Yuan, X.Y. and Fan, Y.B. (2008) In vitro degradation of porous poly(l-lactide-co-glycolide) $/ \beta$-tricalcium phosphate (PLGA $/ \beta$-TCP) scaffolds under dynamic and static conditions. Polymer Degradation and Stability, 93, 1838-1845. http://dx.doi.org/10.1016/j.polymdegradstab.2008.07.007

[44] Aramwit, P., Siritientong, T., Kanokpanont, S. and Srichana, T. (2010) Formulation and characterization of silk sericin-PVA scaffold crosslinked with genipin. International Journal of Biological Macromolecules, 47, 668-675. http://dx.doi.org/10.1016/j.ijbiomac.2010.08.015

[45] Jiang, X.J., Wang, T., Li, X.Y., Wu, D.Q., Zheng, Z.B., Zhang, J.F., Chen, J.L., Peng, B., Jiang, H., Huang, C.X. and Zhang, X.Z. (2009) Injection of a novel synthetic hydrogel preserves left ventricle function after myocardial infarction. Journal of Biomedical Materials Research Part A, 90A, 472-477. http://dx.doi.org/10.1002/jbm.a.32118

[46] Sridharan, I., Kim, T. and Wang, R. (2009) Adapting collagen/CNT matrix in directing hESC differentiation. Biochemical and Biophysical Research Communications, 381, 508-512. http://dx.doi.org/10.1016/j.bbrc.2009.02.072

[47] Zhao, L.Z., Mei, S.L., Chu, P.K., Zhang, Y.M. and Wu, Z.F. (2010) The influence of hierarchical hybrid micro/ nano-textured titanium surface with titania nanotubes on osteoblast functions. Biomaterials, 31, 5072-5082. http://dx.doi.org/10.1016/j.biomaterials.2010.03.014

[48] Dalton, P., H.A., Oudega, M., et al. (2008) Tissue engineering of the nervous system. Tissue Engineering Part A, 611-647.

[49] Hutmacher, D.W., Schantz, J.T., Lam, C.X.F., Tan, K.C. and Lim, T.C. (2007) State of the art and future directions of scaffold-based bone engineering from a biomaterials perspective. Journal of Tissue Engineering and Regenerative Medicine, 1, 245-260. http://dx.doi.org/10.1002/term.24

[50] Klein, T.J., Malda, J., Sah, R.L. and Hutmacher, D.W. (2009) Tissue engineering of articular cartilage with biomimetic zones. Tissue Engineering Part B: Reviews, 15, 143-157. http://dx.doi.org/10.1089/ten.teb.2008.0563

[51] Members, W.G., et al. (2010) Executive summary: Heart disease and stroke statistics-2010 update: A report from the American Heart Association. Circulation, 121, 948954.

http://dx.doi.org/10.1161/CIRCULATIONAHA.109.1926 $\underline{66}$

[52] Martinez, E.C. and Kofidis, T. (2011) Adult stem cells for cardiac tissue engineering. Journal of Molecular and Cellular Cardiology, 50, 312-319. http://dx.doi.org/10.1016/j.yjmcc.2010.08.009

[53] Lopez, J.J., Edelman, E.R., Stamler, A., Hibberd, M.G., Prasad, P., Caputo, R.P., Carrozza, J.P., Douglas, P.S., Sellke, F.W. and Simons, M. (1997) Basic fibroblast growth factor in a porcine model of chronic myocardial ischemia: A comparison of angiographic, echocardiographic and coronary flow parameters. Journal of Pharmacology and Experimental Therapeutics, 282, 385-390.

[54] Kelly, C., Clause, J.P.T., Liu, L.J., Gharaibeh, B., Huard, J., Kirk, J.A., Shroff, S.G., Fujimoto, K.L., Wagner, W.R., Ralphe, J.C., Keller, B.B. and Tobita, K. (2010) A threedimensional gel bioreactor for assessment of cardiomyocyte induction in skeletal muscle-derived stem cells. Tissue Engineering Part C: Methods, 16, 375-385. http://dx.doi.org/10.1089/ten.tec.2009.0098

[55] Hosseinkhani, H., Hosseinkhani, M., Hattori, S., Matsuoka, R. and Kawaguchi, N. (2010) Micro and nano-scale in vitro $3 \mathrm{D}$ culture system for cardiac stem cells. Journal of Biomedical Materials Research Part A, 94A, 1-8. http://dx.doi.org/10.1002/jbm.a.32676

[56] Tulloch, N.L., Muskheli, V., Razumova, M.V., Korte, F.S., Regnier, M., Hauch, K.D., Pabon, L., Reinecke, H. and Murry, C.E. (2011) Growth of engineered human myocardium with mechanical loading and vascular coculture. Circulation Research, 109, 47-59. http://dx.doi.org/10.1161/CIRCRESAHA.110.237206

[57] Leipzig, N.D. and Shoichet, M.S. (2009) The effect of substrate stiffness on adult neural stem cell behavior. Biomaterials, 30, 6867-6878. http://dx.doi.org/10.1016/j.biomaterials.2009.09.002

[58] Li, X., Katsanevakis, E., Liu, X.Y., Zhang, N. and Wen, X.J. (2012) Engineering neural stem cell fates with hydrogel design for central nervous system regeneration. Progress in Polymer Science, 37, 1105-1129. http://dx.doi.org/10.1016/j.progpolymsci.2012.02.004

[59] Saha, K., Irwin, E.F., Kozhukh, J., Schaffer, D.V. and Healy, K.E. (2007) Biomimetic interfacial interpenetrating polymer networks control neural stem cell behavior. Journal of Biomedical Materials Research Part A, 81A, 240249. http://dx.doi.org/10.1002/jbm.a.30986

[60] Aizawa, Y., Leipziga, N., Zahira, T. and Shoichet, M. (2008) The effect of immobilized platelet derived growth factor AA on neural stem/progenitor cell differentiation on cell-adhesive hydrogels. Biomaterials, 29, 4676-4683. http://dx.doi.org/10.1016/j.biomaterials.2008.08.018

[61] Cheng, T.Y., Chen, M.H., Chang, W.H., Huang, M.Y. and Wang, T.W. (2013) Neural stem cells encapsulated in a functionalized self-assembling peptide hydrogel for brain tissue engineering. Biomaterials, 34, 2005-2016. 
http://dx.doi.org/10.1016/j.biomaterials.2012.11.043

[62] Kam, N.W.S., Jan, E. and Kotov, N.A. (2008) Electrical Stimulation of neural stem cells mediated by humanized carbon nanotube composite made with extracellular matrix protein. Nano Letters, 9, 273-278. http://dx.doi.org/10.1021/nl802859a

[63] Prabhakaran, M.P., Ghasemi-Mobarakeh, L., Jin, G.R. and Ramakrishna, S. (2011) Electrospun conducting polymer nanofibers and electrical stimulation of nerve stem cells. Journal of Bioscience and Bioengineering, 112, 501-507. http://dx.doi.org/10.1016/j.jbiosc.2011.07.010

[64] Rao, R.R. and Stegemann, J.P. (2013) Cell-based approaches to the engineering of vascularized bone tissue. Cytotherapy, 15, 1309-1322.

[65] Jose, M.V., et al. (2010) Aligned bioactive multi-component nanofibrous nanocomposite scaffolds for bone tissue engineering. Macromolecular Bioscience, 10, 433-444. http://dx.doi.org/10.1002/mabi.200900287

[66] Maas, M., Guo, P., Keeney, M., Yang, F., Hsu, T.M., Fuller, G.G., Martin, C.R. and Zare, R.N. (2011) Preparation of mineralized nanofibers: Collagen fibrils containing calcium phosphate. Nano Letters, 11, 1383-1388. http://dx.doi.org/10.1021/nl200116d

[67] Ou, K.L., Wu, J., Lai, W.F., Yang, C.B., Lo, W.C., Chiu, L.H. and Bowley, J. (2010) Effects of the nanostructure and nanoporosity on bioactive nanohydroxyapatite/reconstituted collagen by electrodeposition. Journal of Biomedical Materials Research Part A, 92, 906-912.

[68] Lin, C., Wang, Y.F., Lai, Y.Q., Yang, W., Jiao, F., Zhang, H.G., Yea, S.F. and Zhang, Q.Q. (2011) Incorporation of carboxylation multiwalled carbon nanotubes into biodegradable poly(lactic-co-glycolic acid) for bone tissue engineering. Colloids and Surfaces B: Biointerfaces, 83, 367375. http://dx.doi.org/10.1016/j.colsurfb.2010.12.011

[69] Saleh, F.A., Whyte, M. and Genever, P.G. (2011) Effects of endothelial cells on human mesenchymal stem cell activity in a three-dimensional in vitro model. European Cells and Materials, 22, 242-257.

[70] Ordovás, L., Park, Y. and Verfaillie, C.M. (2013) Stem cells and liver engineering. Biotechnology Advances, 31, 10941107.

[71] Wang, Y.J., Zhang, Y., Zhang, S.C., Peng, G.Y., Liu, T., Li, Y.X., Xiang, D.D., Wassler, M.J., Shelat, H.S. and Geng, Y.J. (2012) Rotating microgravity-bioreactor cultivation enhances the hepatic differentiation of mouse embryonic stem cells on biodegradable polymer scaffolds. Tissue Engineering Part A, 18, 2376-2385. http://dx.doi.org/10.1089/ten.tea.2012.0097

[72] Kazemnejad, S., Allameh, A., Soleimani, M., Gharehbaghian, A., Mohammadi, Y., Amirizadeh, N. and Jazayery, M. (2009) Biochemical and molecular characterization of hepatocyte-like cells derived from human bone marrow mesenchymal stem cells on a novel three-dimensional biocompatible nanofibrous scaffold. Journal of Gastroenterology and Hepatology, 24, 278-287.

http://dx.doi.org/10.1111/j.1440-1746.2008.05530.x

[73] Chen, H., et al. (2011) Electrospun chitosan-graft-poly (e-caprolactone)/poly (e-caprolactone) nanofibrous scaffolds for retinal tissue engineering. International Journal of Nanomedicine, 6, 453-461.

[74] Rizk, A. and Rabie, A.B.M. (2013) Human dental pulp stem cells expressing transforming growth factor $\beta 3$ transgene for cartilage-like tissue engineering. Cytotherapy, 15, 712725. http://dx.doi.org/10.1016/j.jcyt.2013.01.012

[75] Jin, G., Prabhakaran, M.P., Kai, D. and Ramakrishna, S. (2013) Controlled release of multiple epidermal induction factors through core-shell nanofibers for skin regeneration. European Journal of Pharmaceutics and Biopharmaceutics, 85, 689-698.

[76] Yin, Z., Chen, X., Zhu, T., Hu, J.J., Song, H.X., Shen, W.L., Jiang, L.Y., Heng, B.C., Ji, J.F. and Ouyang, H.W. (2013) The effect of decellularized matrices on human tendon stem/progenitor cell differentiation and tendon repair. Acta Biomaterialia, 9, 9317-9329.

[77] Aboushwareb, T. and Atala, A. (2008) Stem cells in urology. Nature Reviews Urology, 5, 621-631. http://dx.doi.org/10.1038/ncpuro1228 